\title{
PELAKSANAAN KMA RI NO. 298 TAHUN 2003 PASAL 2 TENTANG PENGAWASAN DAN PENCATATAN PERNIKAHAN PADA MUSIM PANDEMI COVID 19 (Studi Kasus KUA Kecamatan Jombang)
}

\author{
Abd. Basit Misbachul Fitri \\ STAI Darussalam Krempyang Nganjuk Indonesia \\ abdbasitfitri@gmail.com
}

\begin{abstract}
Supervision and registration of marriage is something that is urgent for the sake of being recognized and legislated by the state because it is a very important event. The Indonesian nation has been hit by covid 19 since March 2020 until now it has not ended, this virus is a pandemic category so it is not certain when it will end, spreading throughout the world. The research used the interview method conducted by researchers to Jombang District KUA officers in December 2020 regarding the activities of the KUA Jombang sub-district in the covid 19 pandemic season. The results of this study were the Jombang District Religious Affairs Office still carrying out the task of registering marriage but by using a breakthrough in online registration. according to the specified address, in the supervision of the implementation of the marriage contract council accompanied by Imamuddin in their respective village areas virtually by using video calls and active marriage registration without any rejection of marriage registration. The KUA of Jombang sub-district has also decided to lock down, namely closing the office and imposing WFH (work from home), where work is done from home. This was done in order to anticipate and reduce the spread of the Covid 19 virus because its impact is very dangerous for the safety of life. As the data collected by the


Covid 19 cluster in Jombang sub-district in March-June 2020, Jombang sub-district experienced a red zone in the spread of covid 19, so a breakthrough was needed in the form of policies that provided errors and safety for Jombang sub-district residents in terms of administrative services for recording and implementing marriage contracts. This is done based on maqashid sharia, namely hifd an-Nafs, which is to protect life / soul and also in the form of syad ad-dzariah to prevent mafsadah / damage. The existence of the KUA policy of Jombang sub-district without prejudice to the implementation of the Decree of the Minister of Religion number 298 of 2003 concerning supervision and supervision and registration of marriages.

Keywords : Supervision, Registration of Marriage, the covid-19 pandemic, KUA Jombang District.

\section{PENDAHULUAN}

Pernikahan adalah akad yang menghalalkan hubungan (persetubuhan) antara dua pihak yang berakad dengan aturan-aturan yang ditetapkan syara'. Undang-undang Nomor 1 Tahun 1974 tentang perkawinan menyebutkan bahwa pernikahan adalah "Ikatan lahir batin antara seorang pria dengan seorang wanita sebagai suami istri dengan tujuan membentuk keluarga (rumah tangga) yang bahagia dan kekal berdasarkan Ketuhanan Yang Maha Esa. ${ }^{1}$ Sedangkan menurut agama Islam, perkawinan merupakan salah satu ajaran agama yang dasar hukumnya terdapat di dalam al-Quran dan al-Hadits. Perkawinan juga merupakan sunnah Rasul yang pernah dilakukan Nabi selama hidupnya dan menghendaki umatnya berbuat yang sama, perkawinan merupakan salah satu ayat atau tanda kebesaran Allah Swt. Allah berfirman:

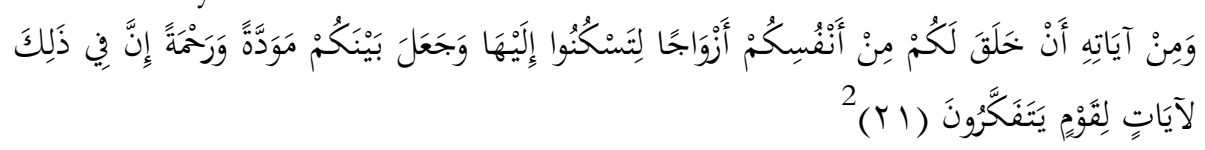

"Di antara tanda-tanda kekuasaan-Nya ialah Dia menciptakan untukmu istri-istri dari jenismu sendiri, supaya kamu cenderung dan merasa tenteram kepadanya, dan dijadikan-Nya diantaramu rasa kasih dan sayang. Sesungguhnya pada yang demikian itu benar-benar terdapat tanda-tanda bagi kaum yang berfikir.”

\footnotetext{
1 MR. Martiman Prodjohamidjojo, Hukum Perkawinan di Indonesia, Pasal 1 Undangundang Nomor 1 Tahun 1974 tentang Perkawinan Indonesia (Jakarta: Legal Center Publishing, 2007), 71

${ }^{2}$ QS. Ar Rum (30): 21.
} 
Dalam Islam perkawinan itu bukan hanya sebuah ikrar biasa seperti halnya ikrarnya pegadaian atau pinjaman dan lain-lain, tetapi perkawinan merupakan sebuah ikrar suci dimana kedua belah pihak dihubungkan menjadi pasangan hidup dengan mempergunakan nama Allah Swt, dengan memenuhi rukun dan syarat nikah. Rukun merupakan unsur yang wajib dipenuhi dalam akad nikah. Sedangkan syarat dijadikan sebagai sandaran untuk sah atau tidaknya suatu akad, karena itu, rukun dan syarat dalam perkawinan dijadikan sebagai hal yang penting yang harus diperhatikan dan dipenuhi guna terlaksananya cita-cita mulia tersebut, yaitu mewujudkan rumah tangga sebagai suatu insitusi yang suci. $^{3}$ Melalui akad nikah yang sah, amalan-amalan sunah yang dilarang atau tidak bisa dijalankan kecuali dengan ikatan pernikahan akan mudah dilakukan, dalam rangka mendekatkan diri kepada Allah SWT dan mendapatkan ridho-Nya.

Perkawinan menurut hukum Islam adalah pernikahan, yaitu akad yang sangat kuat atau mitsaqan ghalidzan untuk mentaati perintah Allah Swt, dan melaksanakannya merupakan ibadah. ${ }^{4}$ Perkawinan dapat diibaratkan sebagai ikrar yang suci dan merupakan tiang utama dalam membentuk suatu keluarga yang baik. Hakikat perkawinan adalah menciptakan kehidupan rumah tangga yang banyak mendatangkan kemaslahatan, baik bagi pelaku perkawinan, anak keturunannya, keluarga atau masyarakat untuk menciptakan keluarga yang sakinah mawaddah warahmah. Begitu pentingnya lembaga ini, maka Islam menentukan sejumlah aturan dan tindakan untuk memperkuat rumah tangga yang dibentuk.

Melakukan pernikahan harus benar-benar dilakukan sesuai aturan yang berlaku baik menurut hukum Islam maupun hukum negara yang sudah memiliki yang baku. Peraturan negara tentang pernikahan diambil dari hukum Islam berdasarkan al-Qur'an dan al-Hadits. dalam melaksanakan akad nikah harus sesuai dengan aturan Islam, negara ketika sudah memenuhi aturan Islam baik dari syarat maupun rukunnya, selanjutnya juga memenuhi aturan yang diwajibkan oleh negara, yaitu berupa pencatatan nikah di Kantor Urusan Agama setempat sebagaimana termaktub dalam Keputusan Menteri Agama Republik Indonesia No. 298 pasal 2 tentang pengawasan dan pencatatan pernikahan.

Dalam melaksanakan akad nikah, naluri setiap manusia ingin mencatatkan pernikahannya pada lembaga pernikahan yang dilegalkan

${ }^{3}$ H. Chuzaiman T. Yanggo \& H A Hafiz Arshary A. Z, Problematika Hukum Islam Kontemporer (Jakarta: PT. Pustaka Firdaus, 2009), 75.

${ }^{4}$ Abdurrahman, Kompilasi Hukum Islam di Indonesia (Jakarta: Akademik Pressindo, 2015), 114. 
oleh pemerintah Indonesia, yakni Kantor Urusan Agama. Lembaga tersebut berwenang melayani administrasi, verifikasi pendaftaran dan pelaksanaan akad nikah, karena Pemerintah mempunyai peran yang sangat vital dalam mengarahkan rakyatnya, khususnya dalam masalah pencatatan pernikahan secara resmi sah menurut agama dan negara. Ketika pelaksanaan akad nikah sudah sesuai menurut agama Islam dalam memenuhi segala aturannya, maka melalui Keputusan Kementerian Agama Republik Indonesia Nomor 298 tentang pencatatan pernikahan pemerintah menjamin tercatatnya pernikahan seseorang ketika dilaksanakan melalui prosedur yang benar menurut aturan pemerintah Indonesia. Karena Tugas pegawai Kantor Urusan Agama akan melaksanakan pencatatan dan pengawasan jalannya proses akad nikah, bila administrasi benar-benar sesuai. Pada situasi saat ini dengan adanya pandemi covid-19, situasinya berbeda dengan keadaan normal, dikarenakan harus memenuhi protokol kesehatan berupa memakai masker, mencuci tangan dengan memakai sabun, membersikan tangan dengan cairan hand sanitizer demi untuk membunuh kuman yang menempel di telapak tangan, larangan berjabat tangan, menjaga jarak dan mengindarkan diri dari kerumunan massa. adanya PSBB (Pembatasan Sosial Berskala Besar) di setiap kota dan kabupaten se Indonesia, bekerja dengan system WFH (work form home) yakni bekerja di rumah banyak kantor yang ditutup sehingga tidak ada pelayanan administrasi dan surat menyurat dan yang terkait dengan perkantoran. Kebijakan ini dilakukan guna mencegah penyebaran covid-19. Melihat realitanya kebutuhan administrasi pencatatann pernikahan tidak bisa ditinggalkan apalagi pencatatan nikah di Kantor Urusan Agama pada semua kecamatan di Indonesia karena administrasi pencatatan pernikahan merupakan bukti dan dokumen resmi yang diakui negara dalam hal menghalalkan yang haram yang dimiliki setiap pasangan suami istri dalam membuktikan keabsahan pernikahan baik menurut agama maupun pemerintah Indonesia. Makanya harus ada strategi yang dijalankan demi memenuhi kebutuhan administrasi tersebut.

Fokus dalam pembahasan ini mengenai pengawasan dan pencatatan pernikahan pada pandemi covid-19 di Kantor Urusan Agama Kecamatan Jombang yang berbeda dalam prosedur pelaksanaan administrasi pencatatan dan pelaksanaan akad nikah jika dibandingkan dengan situasi normal sebelumnya. Mungkin ada terobosan kebijakan strategi baru yang dimiliki Kantor Urusan Agama Kecamatan Jombang dalam melakukan pengawasan dan pencatatan pernikahan yang dilakukan pada musim pandemic covid 19 demi mencegah penyebaran virus yang membahayakan ini. Dasar hukum, yang digunakan KUA Kecamatan Jombang dalam pengawasan dan pencatatan Nikah Sebagaimana 
Keputusan Menteri Agama Republik Indonesia Nomor 298 Tahun 2003 pada bab II Tugas PPN dan Pembantu PPN tertera dalam pasal 2 tentang pencatatan nikah disebutkan : "PPN mempunyai tugas mengawasi dan atau mencatat nikah dan rujuk serta mendaftar cerai talak dan cerai gugat dibantu oleh pegawai pada KUA Kecamatan sebagaimana diatur dalam Undang-undang Nomor 22 tahun 1946 tentang Pencatatan Nikah, Talak dan Rujuk."

\section{Pendekatan Penelitian}

Dalam penyusunan ini peneliti menggunakan pendekatan normatif-yuridis, pendekatan tersebut menggunakan kondisi lingkungan masyarakat kecamatan Jombang dalam menyikapi pelaksanaan keputusan Menteri Agama Republik Indonesia Nomor 298 pasal 2 tentang pengawasan dan pencatatan pernikahan pada musim pandemi covid 19 di KUA kecamatan Jombang menurut hukum Islam dan hukum Positif. Kemudian dianalisa dan komparasikan secara kritis. Adapun bahan kajiannya berasal dari observasi ${ }^{6}$ dan sumber kepustakaan yang antara lain buku-buku dan dokumen. Teknik pengumpulan data secara

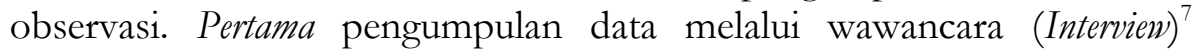
dengan PPN (Pegawai Pencatat Nikah), JFU, Penyuluh Agama Fungsional, di KUA kecamatan Jombang kabupaten Jombang juga para imamudin yang membantu PPN dalam melaksanakan pernikahan di masyarakat. Kedua, dilakukan dengan melalui studi kepustakaan (library research). data yang diperoleh dari literatur yang berkaitan dengan persoalan yang dibahas dalam ini. Yakni pelaksanaan keputusan Menteri Agama Republik Indonesia Nomor 298 pasal 2 tentang pengawasan dan pencatatan pernikahan pada musim pandemi covid 19 di KUA kecamatan Jombang menurut hukum Islam dan hukum Positif.

Analisis data menggunakan tahap content analisis, ${ }^{8}$ menganalisis proses administrasi dengan kenyataannya yakni pelaksanaan keputusan Menteri Agama Republik Indonesia Nomor 298 pasal 2 tentang pengawasan dan pencatatan pernikahan pada musim pandemi covid 19 di KUA kecamatan Jombang menurut hukum Islam dan hukum Positif.

\footnotetext{
5 Pedoman Pembantu Pegawai Pencatat Nikah, Proyek Peningkatan Tenaga Keagamaan Direktorat Jenderal Bimbingan Masyarakat Islam dan Penyelenggaraan Haji Departemen Agama Republik Indonesia, (Jakarta : 2004), 334.

6 Mohamad Mustari dan Taufiq Rahman, Pengantar Metode Penelitian (Yogyakarta: LaksBang Pressindo, 2012), 54.

7 Sandu Siyoto dan M. Ali Sodik, Dasar Metodologi Penelitan (Yogyakarta: Literasi Media Publishing, Juni 2015), 28.

8 A. Muri Yusuf, Metode Penelitian Kuantitatif, Kualitatif \& Penelitian Gabungan (Jakarta: Kencana, 2014), 407-409.
} 
Kemudian analisa tersebut bertujuan untuk menemukan dan mencermati "Pengawasan dan Pencatatan pernikahan pada musim pandemi covid 19 di KUA kecamatan Jombang menurut hukum Islam dan hukum Positif" yang dilakukan di wilayah .

\section{Profil Kantor Urusan Agama Kecamatan Jombang Kabupaten Jombang}

Kantor Urusan Agama (KUA) ini adalah suatu badan organisasi milik Kementerian Agama yang berkedudukan di wilayah kecamatan. KUA Kecamatan Jombang ini bertempat di wilayah Kecamatan Jombang yang mana kecamatan Jombang ini salah satu dari beberapa wilayah kecamatan di Kabupaten Jombang Provinsi Jawa Timur. Sedangkan menurut wilayah Kantor Urusan Agama tingkat kecamatan menurut Peraturan Menteri Agama Indonesia Nomor 34 Tahun 2016, tentang Organisasi dan Tata Kerja KUA Kecamatan disebutkan bahwa KUA adalah unit pelaksana teknis pada Kementerian Agama, berada di bawah dan bertanggung jawab kepada Direktur Jenderal Bimbingan Masyarakat Islam dan secara operasional dibina oleh Kepala Kantor Kementerian Agama Kabupaten/Kota. Yang mana KUA ini adalah instansi yang mempunyai dan melaksanakan tugas dibidang bimbingan masyarakat Islam di wilayah kecamatan.

Dapat dikatakan bahwasannya KUA adalah sebuah instansi milik Kementerian Agama yang berhubungan secara langsung dengan masyarakat, atau dapat dikatakan secara struktural adalah unit kerja Kementerian Agama, namun keberadaanya adalah milik masyarakat. bimbingan keIslaman dan pelayana kepada masyarakat.

Untuk keberadaan KUA Kecamatan Jombang ini beralamatkan di Jl Katamso no. 80 Desa Pulo Lor Kecamatan Jombang Provinsi Jawa Timur luas tanah 553,5 $\mathrm{m} 2$ dan luas banguna $214 \mathrm{~m} 2$ dengan kode pos (61417) dan Nomor telephone (0274), 884821, faxcimile (0274) 884821. Untuk status tanah yang ditempati KUA ini adalah tanah milik pemerintah daerah dan status bangunannya pun juga milik pemerintah daerah.

\section{Wilayah KUA Kecamatan Jombang}

Pada awalnya Kantor urusan Agama ini didirikan di Desa Pulo Lor Kecamatan Jombang Kabupaten jombang. KUA ini memiliki wilayah kerja dalam mengayomi dan melayani masyarakat dari beberapa desa, diantaranya adalah: (1) Kepanjen, (2) Jombatan, (3) Kaliwungu, (4) Jelakombo, (5) Jombang, (6) Denanyar, (7) Candimulyo, (8) Kepatihan, (9) Pulolor, (10) Sengon, (11) Plandi, (12) Sambongdukuh, 
Tunggorono, (14) Dapurkejambon, (15) Tambakrejo, (16) Banjardowo, (17) Sumberjo, (18) Mojongapit, (19) Plosogeneng (20) Jabon.

\section{Visi dan Misi Kantor Urusan Agama Kecamatan Jombang}

Agar terciptanya sebuah keberhasilan dalam melakukan sebuah pekerjaan dan tercapainya tujuan pasti setiap organisasi mempunyai sebuah visi dan misi. Adapun visi Kantor Urusan Agama Kecamatan Jombang "Visi dari Kantor Urusan Agama Kecamatan Jombang adalah "Unggul dalam pelayanan bidang urusan Agama di wilayah Kecamatan Jombang".

Misi Kantor Urusan Agama Kecamatan Jombang :

1) Meningkatkan kualitas SDM untuk menunjang system pelayanan yang berorientasi pada kepuasan masyarakat

2) Meningkatkan kualitas pelayanan nikah dan rujuk

3) Meningkatkan pelayanan dan pembinaan zakat dan wakaf

4) Menigkatkan hubungan dan bimbingan kemasyarakatan

5) Meningkatkan sinergi dengan instansi terkait dalam kegiatan keasyarakatan

\section{Kepemimpinan Kantor Urusan Agama Kecamatan Jombang Kabupaten Jombang}

Kepemimpinan dari sebuah lembaga masyarakat merupakan komponen yang esensial dalam proses perkembangan yang dinamis mengarah kepada selalu meningkatnya kualitas sistem dan produk secara bertahap. Kepala atau pemimpin adalah sebagai pusat untuk kemajuan dari sebuah lembaga atau kelompok. Berikut adalah nama-nama kepala KUA yang pernah memimpin di Kantor Urusan Agama Kecamatan Jombang Kabupaten Jombang : Bashar (1983-1987), Ali Shofwan (19881992), Nur Chamid (1992-1996), Drs. H. Thojib Chamid (1996-2000), H. Zainul Arifin (2000-2004), Ali Taufik, SH. (2005-2009), Drs. Rokhis (2009-2010), Drs. H. Ach. Multazam (2010-2014), Achmad Cholili, S.Ag. M.HI. (2015-2017), H. Miftahul Anwar, S.Ag (2017-2019), H. Hasanuddin, S.Ag., M.Pd.I. (2020- sekarang)

Struktur Pegawai Kantor Urusan Agama Kecamatan Jombang Kabupaten Jombang.

Kepala

Penghulu

JFU/Staff Administrasi

Operator SIMKAH

Penyuluh Agama Islam Fungsional : Husnul Ashari, S.Thi, M.Si.
: H. Hasanuddin, S.Ag. M.Pd.I.

: Aan Sujatmiko, S.Ag.

: Muzayyin, S.T.

: Prima 
- Penyuluh Agama Islam Bidang Produk Halal : H. Ana Miftakhul Syaifuddin, S.Pd.I,

- Penyuluh Agama Islam Bidang Anti Narkoba Dan HIV / AIDS : Hj. Siti Nur Khasanah,

- Penyuluh Agama Islam Bidang Keluarga Sakinah : Hj.Nailil Hidayah, S.Ag,

- Penyuluh Agama Islam Bidang Wakaf : Ahmad Munzir, S.Ag,

- Penyuluh Agama Islam Bidang Anti Radikalisme dan Aliran Sempalan : Hj. Endah Lestiyowati, S.Pd.I.

- Penyuluh Agama Islam Bidang KUB (Kerukunan Umat Beragama) : Abdul Rosyid, S.Pd.

- Penyuluh Agama Islam Bidang Buta Huruf al-Qur'an : Hj. Yunita Tri Pangestutik

- Penyuluh Agama Islam Bidang Zakat : Moch. Choirul Anwar, S.Pd.I.

\section{Jumlah penduduk}

Menurut data yang ada pada tahun 2018. Jumlah penduduk yang ada pada wilayah Kecamatan Jombang sebanyak 95.603 jiwa. Berikut adalah rincian jumlah penduduk menurut agama yang mereka anut: ${ }^{9}$
a. Penduduk yang memeluk agama Islam
: 85.391 jiwa
b. Penduduk yang memeluk agama Kristen
$: 3.139$ jiwa
c. Penduduk yang memeluk agama Katholik
: 6.799 jiwa
d. Penduduk yang memeluk agama Hindu
: 155 jiwa
e. Penduduk yang memeluk agama Budha
: 91 jiwa
f. Penduduk yang memeluk agama Konghucu
: 21 jiwa
g. Penduduk yang memeluk Kepercayaan
: 7 jiwa

\section{Letak Geografis KUA Kecamatan Jombang Kabupaten Jombang}

Kantor Urusan Agama Kecamatan Jombang Kabupaten Jombang ini berada di Desa Pulolor Kecamatan Jombang Kabupaten Jombang dengan batas wilayahnya sebagai berikut: ${ }^{10}$
a. Sebelah Utara
: Wilayah Kecamatan Tembelang
b. Sebelah Selatan
: Wilayah Kecamatan Peterongan
c. Sebelah Barat
: Wilayah Kecamatan Diwek
d. Sebelah Timur
: Wilayah Kecamatan Perak
Sedangkan untuk batas-batas lokasi Kantor sebagai berikut: ${ }^{11}$

\footnotetext{
${ }^{9}$ Papan Grafik kependudukan KUA kecamatan Jombang Kabupaten Jombang

${ }^{10}$ Peta batas wilayah antar kecamatan KUA kecamatan Jombang Kabupaten Jombang

${ }^{11}$ Peta batas lokasi KUA kecamatan Jombang Kabupaten Jombang
} 

a. Sebelah Utara
: Rumah warga
b. Sebelah Selatan
: Jl. Raya Brigjend. Katamso
c. Sebelah Barat
: Kantor partai politik PDIP
d. Sebelah Timur
: Puskesmas Pulolor Jombang

\section{Peosedur Pengawasan dan Pencatatan Pernikahan pada Musim Pandemi Covid 19 Di KUA Kecamatan Jombang}

Prosedur pencatatan pernikahan berbeda karena harus memenuhi protokol kesehatan seperti halnya jaga jarak, larangan berjabat tangan, harus memakai masker, tidak boleh berkerumun banyak orang. Dalam aturan pencatatan pernikahan pemerintah melalui keputusan kementerian Agama Republik Indonesi nomor: 298 tahun 2003 tentang pencatatan pernikahan khususnya pasal 2, didalam peraturan tersebut dijelaskan bahwasannya Pembantu Pegawai Pencatat Pernikahan (P4) ikut mengawasi dan mencatat pelaksanaan akad nikah. Selanjutnya dalam prakteknya P4 datang mengawasi dan mencatat pernikahan di tempat akad pernikahan baik di KUA, maupun di kediaman salah satu calon mempelai pengantin. Akan tetapi pada kondisi sekarang yang di semua tempat diselimuti pandemi covid-19, tentunya berbeda prakteknya dengan mematuhi protokol kesehatan yang ada. di KUA kecamatan Jombang juga menerapkan proses pencatatan pernikahan sesuai protokol kesehatan sebagaimana yang telah disebutkan di atas, salah satunya jaga jarak, dilarang berjabat tangan tentunya dengan kondisi itu sulit bagi P4 untuk menjalankan tugasnya karena juga harus mematuhi protokol kesehatan. Dari sini jelas peraturan pemerintah di atas agak sulit dijalankan oleh P4. Dalam Surat Edaran (SE) nomor : P006/DJ.III/Hk.00.7/06/2020 tentang Pedoman Pelaksanaan Pelayanan Nikah pada Masa Pandemi Covid-19 yang diterbitkan pada tanggal 10 Juni 2020, menyebutkan masyarakat diperkenankan melaksanakan akad nikah di luar KUA.

Meski demikian, ada syarat-syarat administrasi yang harus dipenuhi calon pengantin bila ingin melangsungkan akad nikah di luar KUA. Adapun beberapa Persyaratan antara lain: Pertama, bagi peserta yang mengikuti pelaksanakan prosesi akad nikah di gedung pertemuan atau masjid, diikuti sebanyak-banyaknya 20 persen dari kapasitas ruangan, atau tidak boleh lebih dari 30 orang. Kedua, dalam hal protokol kesehatan dan ketentuan yang di atas tidak dipenuhi, maka penghulu wajib menolak pelayanan nikah disertai dengan alasan secara tertulis diketahui aparat terkait. Ketiga, kepala KUA Kecamatan tetap berkoordinasi tentang rencana penerapan tatanan normal baru pelayanan nikah kepada ketua Gugus Tugas Kecamatan, kecuali menguraikan hal baru terkait 
pernikahan di luar KUA. ${ }^{12}$ H. Ilham Rohim juga membeber perihal pedoman atau aturan pernikahan di masa pandemi secara umum. Hal itu selain berdasarkan Surat Edaran Ditjen Bimas Islam tadi, juga berdasar pada Peraturan Menteri Agama No 20/2019 tentang Percatatan Pernikahan, serta Surat Edaran Menteri Agama Nomor 15/2020 tentang panduan penyelenggaraan kegiatan keagamaan di rumah ibadah dalam mewujudkan masyarakat produktif dan aman Covid-19 di masa pandemi. Aturan-aturan itu guna menjamin pelaksanaan dan pelayanan nikah di tengah Covid 19 yang ditujukan untuk seluruh KUA di Jombang, Di antara pedoman itu, lanjut Bapak $\mathrm{H}$. Ilham Rohim, pendaftaran nikah bisa dilakukan secara online lewat website Simkah.Kemenag.go.id, e-mail, telepon. Tapi bisa juga secara langsung ke KUA, dengan tetap menjalankan protokol pencegahan Covid-19 dan mengurangi kontak fisik dengan petugas KUA. Pelaksanaan akad nikah dapat dilaksanakan di KUA atau di luar kantor. Untuk peserta akad nikah yang diselenggarakan di kantor KUA atau di rumah diikuti sebanyak-banyaknya 10 orang. ${ }^{13}$

\section{Dasar Pencatatan Nikah KUA Kecamatan Jombang}

Menikah merupakan sunnah nabi tetapi juga harus dilembagakan menurut aturan pemerintah Indonesia dalam hal ini Kementerian Agama Republik Indonesia yang menangani, sehingga harus melalui prosedur Keputusan Menteri Agama. Sebelum melangsungkan akad nikah, maka harus menyelesaikan administrasi nikah di KUA setempat demi untuk memperoleh akta nikah. Akta nikah adalah akta perkawinan sebagai bukti keabsahan perkawinan. Sebagaimana dimaksud pasal 12 dan 13 Peraturan Pemerintah No. 9 Tahun 1975 tentang pelaksanaan Undangundang No. 1 tahun 1974 tentang perkawinan. Sedangkan buku nikah adalah kutipan akta nikah yang ditandatangani oleh Penghulu. ${ }^{14}$

Adapun dasar pencatatan nikah adalah tertuang dalam keputusan Menteri Agama Republik Indonesia Nomor 477 Tahun 2004 tentang pencatatan nikah dengan menimbang: Bahwa untuk memenuhi tuntutan perkembangan tata pemerintahan dan peningkatan pelayanan kepada masyarakat, dipandang perlu meninjau kembali keputusan Menteri

\footnotetext{
12 Hasil wawancara dengan kepala KUA Kecamatan Jombang, H. Hasanuddin, S.Ag, M.Pd.I. di kantor KUA Jombang, pada hari Rabu, 23 Desember 2020.

13 Hasil wawancara dengan H. Ilham Rohim, S.Ag, M.HI. di Kementerian Agama Kabupaten Jombang pada hari Selasa, 22 Desember 2020. Hal ini sama sebagaimana pernyataan beliau di media online Kabar Jombang.

14 Keputusan Menteri Agama RI No. 477 Tahun 2004 tentang "Pencatatan Nikab" Diterbitkan Seksi Urusan Agama Islam Kantor Departemen Agama Kota Surabaya Tahun 2005.
} 
Agama Nomor 298 Tahun 2003 tentang Pencatatan Nikah. Adapun undang-undang tersebut sebagaimana berikut:

1) Undang-undang Nomor 22 tahun 1946 tentang pencatatan Nikah, Talak dan Rujuk (Lembaran Negara Tahun 1946 Nomor 98, Tambahan Lembaran Negara Nomor 694);

2) Undang-undang Nomor 32 tahun 1954 tentang penetapan berlakunya Undang-Undang republik Indonesia tanggal 21 Nopember 1946 Nomor 22 Tahun 1946 tentang pencatatan nikah, Talak, Rujuk diseluruh daerah luar Jawa dan Madura (Lembaran Negara Tahun 1954 Nomor 98, Tambahan Lembaran Negara Nomor 694);

3) Undang-undang Nomor 1 Tahun 1974 Tentang Perkawinan (Lembaran Negara Tahun 1974 Nomor 1, Tambahan Lembaran Negara Nomor 3019);

4) Undang-undang Nomor 7 Tahun 1989 tentang Peradilan Agama (Lembaran Negara Tahun 1989 Nomor 49, Tambahan Lembaran Negara Nomor 3400);

5) Undang-undang Nomor 22 Tahun 1999 tentang Pemerintahan Daerah (Lembaran Negara Tahun 1974 Nomor 60, Tambahan Lembaran Negara Nomor 3839);

6) Undang-undang Nomor 18 Tahun 2001 tentang Otonomi Khusus bagi Provinsi Daerah Istimewa Aceh sebagai Provinsi Nangroe Aceh Darussalam (Lembaran Negara Tahun 2001 Nomor 114, Tambahan Lembaran Negara Nomor 4134);

7) Peraturan Pemerintah Nomor 9 Tahun 1975 tentang pelaksanan Undang-Undang Nomor 1 Tahun 1974 tentang perkawinan, (Lembaran Negara Tahun 1975 Nomor 12, Tambahan Lembaran Negara Nomor 3250);

8) Keputusan Presiden Nomor 102 Tahun 2001 tentang Kedudukan, Fungsi, Kewenangan, Susunan Organisasi dan Tata Kerja Departemen sebagaimana telah beberapa kali diubah, terakhir dengan Keputusan Presiden Nomor 22 Tahun 2004;

9) Keputusan Presiden Nomor 109 Tahun 2001 tentang Unit Organisasi dan Tugas Eselon I Departemen sebagaimana telah beberapa kali diubah, terakhir dengan Keputusan Presiden Nomor 77 Tahun 2004;

10) Keputusan Presiden Nomor 11 Tahun 2002 tentang Mahkamah Syar'iyah Propinsi di Propinsi Nangroe Aceh Darussalam;

11) Keputusan Presiden Nomor 49 Tahun 2002 tentang Kedudukan, Fungsi, Kewenangan, Susunan Organisasi dan Tata Kerja Instansi Vertikal Departemen Agama yang telah diubah dengan keputusan Presiden Nomor 85 Tahun 20042. 
12) Keputusan Bersama Menteri Agama dengan Menteri Luar Negeri Nomor 589 Tahun 1999 dan Nomor 182/OT/X/99/01 Tahun 1999 tentang Petunjuk Pelaksanaan Perkawinan Warga Negara Indonesia di Luar Negeri;

13) Keputusan Menteri Agama Nomor 1 Tahun 2001 tentang kedudukan, Fungsi, Kewenangan, Susunan Organisasi dan Tata Kerja Departemen Agama;

14) Keputusan Menteri Agama Nomor 517 Tahun 2001 tentang penataan organisasi Kantor Urusan Agama Kecamatan;

15) Keputusan Menteri Agama Nomor 373 Tahun 2002 tentang Organisasi dan Tata Kerja Kantor Wilayah Departemen Agama Provinsi dan, Kantor Departemen Agama Kabupaten/Kota, sebagaimana telah diubah dengan Keputusan Menteri Agama Nomor 480 Tahun 2003; ${ }^{15}$

16) Keputusan Menteri Pendayagunaan Aparatur Negara Nomor Kep/42/M-PAN/4/2004 tentang jabatan Fungsional Penghulu;

17) Keputusan Menteri Agama Nomor 301 Tahun 2004 tentang Petunjuk Pelaksanaan Jabatan Fungsional Penghulu.

\section{Prosedur Administrasi dan Pendaftaran Nikah di KUA kecamatan Jombang di musim pandemi Covid 19.}

KUA Kecamatan Jombang dalam menyikapi musim pandemi ini tetap menjalankan aktvitasnya, akan tetapi dengan cara mengurangi jam kerja dan mengurangi kegiatan juga pegawai yang bertugas di kantor. Begitu juga pelayanan pendaftaran nikah semakin dibatasi, karena pendaftaran pernikahan masyarakat tidak mungkin ditolak. KUA Kecamatan Jombang mempunyai terobosan tersendiri dalam hal pendaftaraan dan pelaksanaan nikah, Kepala KUA Kec. Jombang memberikan wewenang kepada Imamuddin/P4 untuk menerima pendafataran nikah dan melaksanakan pernikahan di desanya masingmasing dan dicatat di buku Register Nikah Desa. Pemohon atau masingmasing calon pengantin melengkapi Administrasi pencatatan nikah diantaranya: ${ }^{16}$ Foto copy KTP, Kartu Keluarga, Akta Kelahiran, Ijazah Terakhir, foto berwarna ukuran $3 \times 44$ sebanyak lembar, laki-laki background warna merah, perempuan background warna biru, dan ukuran 4X6 sebanyak 2 lembar, dengan melengkapi surat-surat dari

15 Pedoman Pembantu Pegawai Pencatat Nikah, Proyek Peningkatan Tenaga Keagamaan Direktorat Jenderal Bimbingan Masyarakat Islam dan Penyelenggaraan Haji Departemen Agama Republik Indonesia, (Jakarta : 2004), 331-332.

16 Juknis pandaftaran dan pencatatan nikah KUA Kecamatan Jombang kabupaten Jombang 
pemerintahan desa masing-masing berupa $\mathrm{N} 1$ biodata dan status calon pengantin, N2 untuk permohonan kehendak nikah, N4 untuk persetujuan calon calon pengantin, N5 untuk surat izin orang tua calon pengantin, bagi calon pengantin yang berstatus sebagai duda atau janda mati, maka harus melampirkan surat N6 yakni surat keterangan kematian asli dari pemerintah desa tempat pemakaman mantan isteri atau suami, dan bagi calon pengantin berstatus sebagai duda atau janda cerai, maka harus melampirkan akta cerai asli yang dikeluarkan oleh Pengadilan Agama yang mewilayahi domisili suami isteri. Jika pelaksanaan nikah di kantor, maka menggunakan biaya gratis tetapi jika pelaksaan akad nikah dilaksanakan secara bedol di (luar kantor) Calon pengantin diharuskan membayar adminitrasi Pencatatan nikah bedol Sebanyak Rp. 600.000, yang harus dibayar kepada pemerintah melalui BRI atau Ebilling, bukti pembayarannya diberikan kepada KUA Jombang. lalu didaftarkan Imamuddin/P4 kepada KUA kecamatan Jombang. Meskipun dalam keadaan musim pandemi covid 19 KUA kecamatan Jombang, tentunya dengan tetap menjalankan tertib administrasi pencatatan nikah tanpa terkurangi sedikitpun sebagaimana keputusan Ditjen Nomor, 298 tahun $2003 .^{17}$

\section{Kelengkapan administrasi pendaftaran kehendak nikah di KUA Kecamatan.}

Adapun prosedur pendaftaran nikah di KUA Kecamatan: ${ }^{18}$

1. Setiap penduduk yang akan melangsungkan perkawinan memberitahukan kehendaknya kepada KUA Kecamatan, baik secara lisan atau tertulis, oleh calon pengantin, atau oleh orang tua atau wakilnya dengan membawa beberapa persyaratan administrasi pendaftaran nikah.

2. Pemberitahuan tersebut memuat nama, umur, agama, pekerjaan, tempat kediaman calon pengantin dan apabila salah seorang atau keduanya pernah kawin, disebutkan juga nama isteri atau suami terdahulu.

3. Pemberitahuan tersebut dilakukan sekurang-kurangnya 10 (sepuluh) hari kerja sebelum perkawinan dilangsungkan.

4. Pengecualian terhadap jangkan waktu tersebut, disebabkan suatu alasan yang penting, diberikan oleh Camat atas nama Bupati sebagai Kepala Daerah Kabupaten Jombang.

17 Hasil wawancara dengan Penghulu JFU (Jabatan Fungsional Umum) KUA Kecamatan Jombang, Bapak Aan Sujatmiko, S.Ag, al-Hafidz, di kantor KUA Jombang, pada hari Rabu, 24 Desember 2020.

${ }^{18}$ Hasil wawancara peneliti dengan Kepala KUA Kecamatan. 
5. Pegawai Pencatat yang menerima pemberitahuan kehendak nikah meneliti syarat-syarat perkawinan, apakah sudah dipenuhi dan apakah terdapat halangan perkawinan menurut Undang-undang.

6. Setelah diperiksa ternyata persyaratan pemberitahuan kehendak nikah sudah lengkap, dan tidak ada sesuatu halangan perkawinan, kemudian hasil penelitian tersebut ditulis oleh Pegawai Pencatat dalam sebuah daftar pencatatan nikah.

7. Pegawai Pencatat nikah menyelenggarakan pengumuman tentang pemberitahuan kehendak melangsungkan perkawinan yang telah ditandatangani oleh Pegawai Pencatat nikah dengan cara menempelkan surat pengumuman menurut formulir pada tempat yang sudah ditentukan pada KUA dan mudah dibaca, yang memuat:

- Nama, umur, agama, pekerjaan, tempat kediaman calon pengantin dan dari orang tua calon pengantin, apabila salah seorang atau keduanya pernah kawin disebutkan nama isteri atau suaminya terdahulu.

- Hari, tanggal, jam dan tempat akad nikah dilangsungkan (biasanya akad nikah berada dikediaman calon pengantin wanita).

\section{Dasar Hukum Akad Nikah}

Dalam Keputusan Menteri Agama Republik Indonesia No. 477 tahun 2004 tentang pencatatan nikah pada pasal 18, 19, 20, 21 dan 22 Bab IX tentang akad nikah disebutkan beberapa hal yang menyangkut proses akad nikah disertai pencatatannya di KUA Kecamatan yang dilakukan oleh Penghulu atau Pembantu Penghulu sebagai berikut:

Disebutkan pada pasal 18 yaitu;

a. Penghulu atau Pembantu Penghulu tidak boleh meluluskan akad nikah sebelum 10 (sepuluh) hari sejak pengumuman.

b. Pengecualian terhadap jangka waktu tersebut pada ayat (1) disebabkan suatu alasan yang penting, diberikan dispensasi oleh Camat.

c. Dalam waktu 10 (sepuluh) hari sebelum Penghulu atau Pembantu Penghulu meluluskan akad nikah, calon suami isteri diharuskan mengikuti khusus calon pengantin dari badan penasehatan, pembinaan dan pelestarian perkawinan (BP4) setempat. Juga disebutkan pada pasal 19 yaitu:

(1) Akad nikah dilaksanakan dihadapan Penghulu atau Pembantu Penghulu di luar jawa yang mewilayahi tempat tinggal calon isteri dan dihadiri oleh dua orang saksi.

(2) Saksi yang hadir pada waktu akad nikah, harus beragama Islam, sudah mencapai umur 19 (sembilan belas) tahun dan memenuhi syarat-syarat menurut hukum. 
(3) Keluarga dekat, pegawai KUA atau Pembantu Penghulu dapat diterima sebagai saksi.

(4) Akad nikah dilakukan oleh wali nasab.

(5) Apabila akad nikah dilaksanakan di luar ketentuan ayat (1), maka calon isteri atau walinya harus memberitahukan kepada Penghulu atau Pembantu Penghulu yang mewilayahi tempat tinggal tempat calon isteri untuk mendapatkan surat rekomendasi nikah.

(6) Wali nasab dapat mewakilkan kepada Penghulu atau Pembantu Penghulu atau orang lain yang menurut Penghulu atau Pembantu Penghulu dianggap memenuhi syarat.

(7) Penghulu menjadi wali hakim karena calon pengantin tidak mempunyai wali nasab, atau walinya mafqud, atau adal.

(8) Dalam hal adalnya wali sebagaimana tersebut pada ayat (7) ditetapkan dengan Keputusan Pengadilan.

Juga disebutkan pada pasal 20 yaitu;

(1) Akad nikah dilaksanakan di KUA oleh Penghulu.

(2) Atas permintaan calon pengantin yang bersangkutan akad nikah dapat dilaksanakan diluar KUA Kecamatan dengan persetujuan Penghulu.

Juga disebutkan pada pasal 21 yaitu:

(1) Calon suami dan wali wajib datang sendiri menghadap Penghulu atau Pembantu Penghulu pada waktu akad nikah.

(2) Dalam hal calon suami atau wali tidak dapat hadir waktu nikah, maka ia dapat mewakilkan pada orang lain.

(3) Wakil sebagaimana dimaksud dalam ayat (2) dikuatkan dengan surat kuasa yang disahkan oleh Penghulu atau Pembantu Penghulu atau oleh Kepala Perwakilan Republik Indonesia apabila calon suami atau wali berada di luar negeri.

Juga disebutkan pada pasal 22 yaitu:

(1) Apabila pada waktu pemeriksaan nikah calon pengantin mensetujui taklik talak sebagaimana dimaksud dalam pasal 10 ayat (3), maka suami membaca dengan melafalkan atau dalam hati dan menandatangani taklik talak setelah akad nikah dilaksanakan.

(2) Apabila waktu akad nikah suami mewakilkan qabul kepada orang lain, maka taklik talak dibaca dan ditandatangani oleh suami pada waktu lain dihadapan Penghulu atau Pembantu Penghulu tempat akad nikah dilaksanakan.

Apabila dalam pemeriksaan akad nikah ada persetujuan taklik talak tetapi setelah akad nikah suami tidak mau membaca 
dan menandatangani, maka isteri berhak mengajukan kepada Pengadilan agar persetujuan tentang taklik talak ditepati. ${ }^{19}$

\section{Praktek dan Tata Cara Upacara Akad Nikah}

Tata cara upacara akad nikah adalah proses pelaksanaan akad nikah dari permulaan sampai penandatanganan pada daftar pemeriksaan nikah oleh masing-masing yang berhak dan selanjutnya dicatat dalam akta nikah. Dengan demikian sah dan resmilah pernikahan tersedut dengan dilaksanakan menurut hukum agama dan terrcatat menurut peraturan perundang-undangan yang berlaku.

Petunjuk tata cara upacara akad nikah tercantum dalam edaran ditjen bimas Islam dan urusan haji nomor E11/02 ED/PW.00/03/83 tertanggal 06 maret 1984.

1. Waktu dan pelaksanaan akad nikah

Akad nikah dilangsungkan setelah lewat 10 hari kerja terhitung sejak tanggal pengumuman, apabilah akad nikah akan dilangsungkan kurang dari 10 hari kerja tersebut, karena suatu alasan yang penting harus ada dispensasi dari camat atas nama bupati kepala daerah.

2. Tempat pelaksanaan akad nikah

Tempat dilangsungkan akad dapat dilaksanakan:

a. Di balai nikah atau KUA kecamatan yang di ruang khusus lengkap dengan perlengkapannya, atau di tempat tinggal pembantu PPN (Pegawai Pencatat Nikah)

b. Di luar balai nikah atau di luar di tempat tinggal pembantu PPN (Pegawai Pencatat Nikah) seperti di rumah calon isteri atau masjid, yang pengaturannya diserahkan kepada yang mempunyai hajat.

3. Yang menghadiri akad nikah

a. Pembantu PPN

b. Wali nikah atau wakilnya

c. Calon suami atau wakilnya.

d. Calon istri (sesuai keadaan setempat).

e. Dua orang saksi yang memenuhi syarat.

f. Para pengantar/undangan

4. Pelaksanaan akad nikah

Rangkaian pelaksanaan akad nikah diatur sebagai berikut:

\footnotetext{
${ }^{19}$ Keputusan Menteri Agama RI. No. 477 Tahun 2004 tentang, "Akad Nikab”, Bab.
} IX pasal 18, 19, 20, 21 dan 22, 8- 9. 
a. Pembantu PPN terlebih dahulu memeriksa ulang tetang persyaratan nikah dan administrasinya kepada calon pengantin dan wali, kemudian emnetapkan dua orang saksi yang memenuhi syarat

b. Pembantu PPN menanyakan kepada calon isteri di hadapaan dua orang saksi, apakah dia bersedia dinikahkan dengan calon calon suaminya atau tidak

c. Jika calon isteri bersedia, dipersilahkan meminta kepada walinya untuk dinikahkan dengan calon suaminya, kemudian pembantu PPN menanyakan kepada wali, apakah dia sendiri yang akan mewalikan anaknya atau mewakilkan.

d. Sebelum akad nikah dilaksanakan, dapat didahului dengan:

1. Pembacaan ayat suci al-Qur'an

2. Pembacaan khutbah nikah

3. Pembacaan Istighfar dan Syahadatain secara bersama-sama dipimpin oleh Pembantu PPN atau wali yang akan melakukan ijab.

e. Pelaksanaan akad nikah

1. Ijab oleh wali nasab

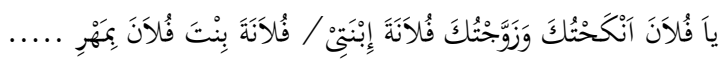
"Hai Fulan bin ................., saya nikahkan engkau dengan anak perempuan saya/saudara perempuan saya dengan mas kawin....................".

Di dalam ijab juga diberi tambahan, jika di daerah setempat memerlukannya, seperti:

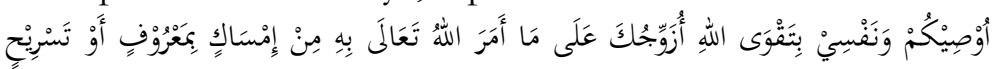

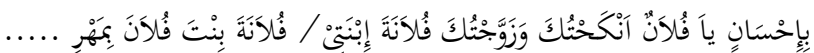

2. Qabul oleh calon suami

"Saya terima nikahnya fulanah binti

dengan maskawin tersebut."

f. Apabila wali mewakilkan kepada Pembantu PPN/Penghulu, maka wali harus mengatakan:

"Bapak Penghulu/Naib (istilah yang larim dipakai setempat) saya mewakilkan kepada Bapak untuk mewalikan dan menikabkan Fulanah, anak perempuan saya/saudara perempuan saya dengan Fulan bin dengan maskawin .".

Pembantu PPN/Penghulu menjawab :

"Saya terima untuk mewalikan dan menikabkan Fulanah binti.............. dengan Fulan bin ................ dengan maskawin ". 
g. Apabila yang menikahkan itu bukan walinya, maka $i>j a>b n n y a$ sebagai berikut:

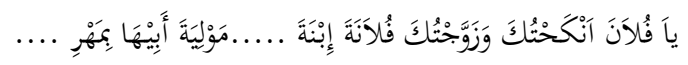

"Hai Fulan bin ........................, saya nikabkan engkau....................yang walinya mewakilkan kepada saya dengan Fulanab binti Fulan dengan maskawin ........................".

h. Setelah ijab qabul dilaksanakan, Pembantu PPN/Penghulu menanyakan kepada saksi-saksi, apakah ijab qabul sudah sah apa belum. Apabila saksi-saksi menyatakan belum sah, maka ijab qabul diulang kembali sampai dinyatakan sah.

Apabila sudah sah, maka dibacakan:

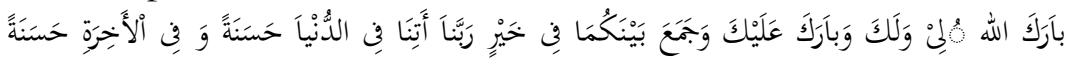

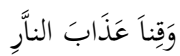

i. Pembacaan Doa.

j. Pembantu Penghulu/Penghulu menawarkan kepada pengantin laki-laki untuk membacakan taklik talak yang sudah disiapkan. Apabila suami tidak bersedia membaca, maka harus diberitahukan kepada isteri, bahwa suaminya tidak mengikrarkan taklik talaq

k. Penandatanganan surat-surat yang diperlukan:

- Suami, isteri, wali, dua orang saksi dan Pembantu Penghulu/Penghulu membubuhkan tanda tangan pada halaman 4 Daftar Pemeriksaan Nikah (model NB).

- Suami menandatangani ikrar taklik talak, jika telah mengikrarkannya.

1. Pembantu Penghulu menyatakan kepada hadirin bahwa upacara akad nikah telah selesai dan kedua pengantin dianggap telah sah menurut hukum sebagai suami isteri.

Jika perlu dapat ditambahkan penyuluhan/penasehatan, antara lain:

- Yang berhubungan dengan masalah nikah.

- Hak dan kewajiban suami isteri.

- Kehidupan rumah tangga bahagia.

m. Nasehat perkawinan.

n. Kedua pasangan suami isteri bersalaman kepada ibu bapak, kedua belah pihak dan keluarga terdekat, selanjutnya menerima ucapan 
selamat dari para undangan (sesuai dengan adat yang tidak bertentangan dengan syari'at Islam).$^{20}$

\section{Pelaksanaan KMA RI Nomor 298 pasal 2 tentang pengawasan dan pencacatatan pernikahan pada musim pandemi covid 19 di KUA kecamatan Jombang ${ }^{21}$}

KUA Kecamatan Jombang dalam melaksanakan pengawasan dan pencatatan pernikahan pada musim pandemi ini masih menjalankan aktivitasnya dengan menggunakan kebijakan baru berdasarkan intruksi kasie Bimas Islam kemenag Jombang. Adapun kebijakan Strategi yang dampak covid 19 berpengaruh pada pelaksanaan pernikahan di KUA kecamatan Jombang, sehingga diberlakukan kebijakan aktivitas sebagaimana berikut: ${ }^{22}$

1. KUA kecamatan Jombang disaat parahnya musim pandemi diberlakukan lock down (tutup kantor dan pelayanan) sementara beberapa waktu,

2. Ketika kondisi aman diberlakukan system jaga piket secara bergantian antar pegawai KUA kecamatan Jombang

3. Pelayanan administrasi berupa apapun ditutup karena demi keamanan

4. Disiapkan pendaftaran nikah secara online dengan beberapa model :

a). Layanan Online WA Bisnis KUA Jombang beralamatkan https://wa.me/6289652616334?text=Assalamu\%20Alaikum\%2 0kantor\%20Urusan\%Agama\%20Kec.\%20Jombang

b). Pendaftaran Nikah Secara Online: http://simkah.kemenag.go.id/daftarnikah/create.

c.) Petunjuk penggunaan download di: https://bimasislam.kemenag.gp.id/uploads/files/PETUNJUK \%20PENDAFTARAN $\% 20$ NIKAH $\% 20$ ONLINE $\% 20$ SIMKA H\%20WEB.pdf

d.) Berkas diantarkan ke KUA Kecamatan Jombang maksimal 3 hari kerja setelah pendaftaran online.

5. Pernikahan di Kantor Urusan Agama Jombang, cukup dihadiri calon pengantin (suami-istri), wali nikah dan 2 (dua) orang saksi, selain itu dilarang masuk.

\footnotetext{
${ }^{20}$ Pedoman Pembantu Pegawai Pencatat Nikah, Proyek Peningkatan Tenaga Keagamaan Direktorat Jenderal Bimbingan Masyarakat Islam dan Penyelenggaraan Haji Departemen Agama Republik Indonesia, (Jakarta : 2004), 47-51

${ }^{21}$ Hasil wawancara dengan kepala KUA Kecamatan Jombang, H. Hasanuddin, S.Ag, M.Pd.I. di kantor KUA Jombang, pada hari Rabu, 23 Desember 2020.

22 Hasil wawancara dengan JFU KUA Kecamatan Jombang, Bapak Aan Sujatmiko, S.Ag, al-Hafidz, di kantor KUA Jombang, pada hari Rabu, 24 Desember 2020.
} 
6. Pelaksanaan pernikahan berupa akad nikah dipercayakan kepada imamuddin selaku pembantu Pegawai Pencatat Nikah di wilayahnya, sementara Pegawai KUA tidak bisa hadir di acara akad nikah karena khawatir terjadi penyebaran virus covid-19 tetapi tetap berpegang menjalankan peraturan pencatatan nikah

7. Penyaksian pelaksaaan akad nikah dilakukan via zoom dan video call whatapps sebagai bentuk pengawasan yang dilakukan Pegawai Pencatat Nikah KUA Jombang terhadap pelaksanaan pernikahan.

\section{KUA Kecamatan Jombang Lockdown di Musim Pandemi}

Pada permulaan terjadinya covid-19 KUA Kecamatan Jombang dan dengan alasan Demi menjaga keamanan covid-19 kepala KUA Jombang, H. Hasanuddin, M.Pd.I. melakukan lockdown yakni tutup sementara waktu dikarenakan kecamatan Jombang termasuk zona merah dalam penyebaran virus covid 19. Kebijakan lockdown ini dilaksanakan ketika awal bulan Ramadlan-Syawal $1441 \mathrm{H}$ atau bertepatan dengan kalender bulan Mei-Juni 2020. Disamping itu juga utuk mematuhi Surat Edaran Bupati Jombang $\mathrm{Hj}$. Mundjidah Wahab, Nomor 800/1019/415.41/2020, tertanggal 24 Maret 2020. Menindak Terkait pengurangan jam kerja, mengurangi luar kota, memakai hand sanitizer dan menjalankan protokler kesehatan bagi Aparatur Sipil Negara di lingkungan kabupaten Jombang. Akan tetapi penyebaran virus covid-19 di kabupaten jombang mengalami peningkatan secara signifikan, yakni perkebangannya semakin pesat. Pasien virus covid 19 pada tanggal 25 mei 2020 sejumlah 50 orang semakin bertambah pada 30 juli 2020 menjadi 140, 04 oktober 2020 meningkat menjadi 155 orang. Data terakhir dirilis pada tanggal 9 desember 2020 pasien Covid 19 sejumlah 225 orang. ${ }^{23}$ Semoga mereka diberikan kesembuhan oleh Allah Swt,.

\section{Pelaksanaan KMA RI Nomor 298 pasal 2 tentang pengawasan dan pencatatan pernikahan pada musim pandemi covid 19 di KUA kecamatan Jombang menurut Hukum Islam dan Hukum Positif}

Pelaksanaan pernikahan pada musim pandemi covid 19 yang dilakukan oleh imamuddin di wilayahhnya masing masing tanpa dihadiri dan disaksikan oleh PPN KUA Kecamatan Jombang setelah melakukan pendaftaran secara online dapat dibenarkan oleh hukum pencatatan perkawinan di Indonesia. Kelonggaran kebijakan ini menjadi dasar hukum pelaksanaan akad nikah di musim pandemic dan sangat menguntungkan bagi petugas KUA demi mengunrangi dan mencegah adaya penyebaran Virus covid 19 dan

\footnotetext{
${ }^{23}$ Sumber : JHU CSSE COVID-19 Jombang.
} 
Menurut Peraturan Menteri Agama Republik Indonesia Nomor 19 tahun 2018 tentang pencatatan perkawinan tertera pada pasal 16 ayat 1 dan 2 berbunyi :

(1) Akad dilaksanakan di hadapan kepala KUA Kecamatan atau penghulu yang mewilayahi tempat akad dilaksanakan

(2) Dalam hal pelaksanaan akad dilaksanakan di daerah terdalam, terluar dan daerah perbatasan, kepala KUA Kecamatan dapat menugaskan P4.

Tindakan imamuddin dalam pengawasan pernikahan bisa menggantikan PPN ketika PPN berhalangan hadir mendapat perlindungan secara hukum. Hal ini disamakan dengan tugas pembantu PPN di luar Jawa yang mempunyai peran membantu PPN sebagaimana dikuatkan dalam keputusan Menteri Agama Republik Indonesia Nomor 298 Tahun 2003 pasal 4 yakni :

(1) Pembantu PPN di luar Jawa atas nama PPN mengawasi nikah dan menerima pemberitahuan rujuk yang dilakukakn menurut agama Islam di wilayahnya." ${ }^{24}$

Sedangkan tugas pembantu PPN sebagaimana pasal 4 ayat 2 :

(2) Pembantu PPN di Jawa membantu mengantar anggota masyarakat di wilayahnya yang berkepentingan dengan KUA Kecamatan / PPN yang mewilayahi dalam hal pemeriksaan nikah dan atau rujuk serta mencatat kehendak nikah dan atau rujuk tersebut dalam buku menurut model N-10 dan R-2. ${ }^{25}$

\section{Menurut hukum positif di Indonesia}

Kebijakan yang dilakukan pemimpin di wilayah tugasnya dalam hal ini kepala KUA kecamatan Jombang merupakan aturan dan perundangan yang harus diikuti oleh masyarkaat, maka kita sebagai warga negara wajib menjalankannya, selama perintah/peraturan tersebut tidak melanggar syari'at Islam. Sebagaimana Firman Allah SWT:

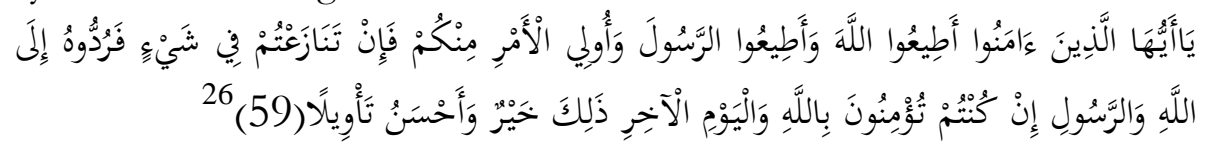

\footnotetext{
24 Pedoman Pembantu Pegawai Pencatat Nikah, Proyek Peningkatan Tenaga Keagamaan Direktorat Jenderal Bimbingan Masyarakat Islam dan Penyelenggaraan Haji Departemen Agama Republik Indonesia, (Jakarta : 2004), 335.

25 Pedoman Pembantu Pegawai Pencatat Nikah, Proyek Peningkatan Tenaga Keagamaan Direktorat Jenderal Bimbingan Masyarakat Islam dan Penyelenggaraan Haji Departemen Agama Republik Indonesia, (Jakarta : 2004), 336.

${ }^{26}$ QS. An Nisa' (04): 59
} 
"Hai orang-orang yang beriman, ta`atilah Allah dan ta`atilah Rasul (Nya), dan ulil amri di antara kamu. Kemudian jikea kamu berlainan pendapat tentang sesuatu, maka kembalikanlah ia kepada Allab (Al Qur'an) dan Rasul (sunnabnya), jika kamu benar-benar beriman kepada Allah dan hari kemudian. Yang demikian itu lebih utama (bagimu) dan lebih baik akibatnya" (Q.S An-Nisa' ayat 59)

Ayat tersebut memerintahkan (mewajibkan) pada umat Islam agar patuh terhadap perintah seorang pemimpin negara seperti yang tertera

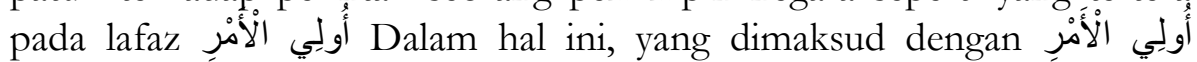
adalah pemerintahan suatu negara. Dimana keputusan pemerintah dalam hal ini itu harus diikuti karena kita berada pada suatu negara yang mempunyai aturan yang harus diikuti. Undang-undang tersebut merupakan peraturan pemerintah, maka setiap warga negara khususnya yang beragama Islam wajib memamatuhi peraturan tersebut sesuai dengan surat an-Nisa' ayat 59, sebagaimana di atas. Perintah wajib

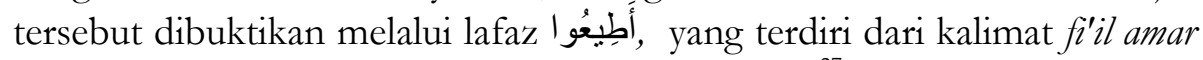
yang menunjukkan arti lil wujub (harus dilakukan). ${ }^{27}$

Dalam kaidah fiqhiyyah ketika kita diperintahkan menjalankan suatu ibadah, maka secara otmatis kita juga diperintahkan menjalankan sesuatu yang menjadi wasilah mengantarkan suksesnya ibadah tersebut:

$$
\text { الأمر بالشيء الأمر بوسائله }
$$

"Perintah terhadap sesuatu juga perintah terbadap wasilahnya (perantara)" 28

Jika dilihat dari Tujuan adanya kebijakan pengawasan pencatatan pernikahan KUA kecamatan Jombang bagi pendaftaran nikah oleh kepala KUA Jombang dalam memberikan kewenangan kepada pembantu PPN dalam menerima pendaftaran nikah secara online sesuai alamat yang ditentukan KUA Jombang dan dilanjutkan melakukan akad nikah di rumah mempelai pengantin perempuan, sehingga pegawai KUA Jombang bertugas mengawasi secara virtual berupa video call saja dan tidak perlu hadir dalam pelaksanaan majelis akad nikah, disamping juga untuk memberdayakan para imamuddin dalam menjalankan tugas pencatatan dan pelaksanaan akad nikah adalah bentuk kebijakan dalam pencegahan penyebaran Covid -19 di kecamatan Jombang yang berdasarkan pada maqashid syariah, yakni maqashid yang artinya kesengajaan atau tujuan, dan Syari'ah yang artinya jalan menuju sumber pokok kehidupan. ${ }^{29}$ maqashid syari'ab yang berjumlah ada lima unsur

\footnotetext{
27 Abdul Hamid Hakim, as-Sullam, juz II, hal. 60.

${ }^{28}$ Ibid.

${ }^{29}$ Totok Jumantoro, Kamus Usul Fiqh (Jakarta: Sinar Grafika, 2005), 196.
} 
pokok berupa agama (bifdz ad-din), jiwa (bifdz an-Nafsi), akal (bifdz aq), keturunan (bifdz, an-nasl) dan harta (hifdz, mal) dalam hal ini tujuan pokok kebijakan kepala KUA kecamatan Jombang berupa menjaga jiwa/ nyawa (bifdz an-Nafsi) mejadi alasan utama, karena virus covid 19 sangat membahayakan bagi nyawa. ${ }^{30}$

Begitu juga ketika dikaitkan dengan kaidah fiqhiyyah terdapat larangan terhadap sarana yang mendatangkan pada perbuatan yang dilarang itulah penetapan hukum beerdasarkan pada "Syadd al-Dzari"ab". Perbuatan-perbuatan yang menjadi wasilah kepada kebinasaan,lanjut Abdul Karim Zaidan terbagi kepada dua macam yaitu:

1. Perbuatan yang keharamannya bukan saja karena ia sebagai wasilah bagi sesuatu yang di haramkan,tetapi esensi perbuatan itu sendiri adalah haram.

2. Perbuatan yang secara esensial dibolehkan (mubah),namun perbuatan itu memungkinkan untuk digunakan sebagai wasilah kepada sesuatu yang di haramkan. ${ }^{31}$

Kebijakan ini Juga dikuatkan memberikan kemaslabatan (kebaikan) kepada masyarakat kecamatan Jombang khususnya untuk menghindari adanya kemafsadatan (kerusakan) berupa kerusakan atau timbulnya virus covid 19 yang mengakibatkan kematian. Sebagaimana dalam kaidah fiqhiyah :

"Menolak kemafsadatan (kerusakan) lebih didabulukan untuke menarik kemaslabatan (kebaikan)".

Oleh karena tujuan utama kepala KUA dalam menerbitkan kebijakan berupa pengawasan secara virtual berupa video call oleh imamuddin dalam pelaksanaan akad nikah ini dibenarkan menurut agama dan peraturan pemerintah berupa Keputusan Menteri Agama Republik Indonesia nomor 298 tahun 2003 pasal 2 tentang pengawasan dan pencatatan pernikahan pada musim pandemi covid 19 di KUA Kecamatan Jombang kabupaten Jombang

\section{Daftar Pustaka}

Hakim, Abdul Hamid. as-Sullam, juz II, Surabaya : al-Hidayah, 1998. Abdurrahman, Kompilasi Hukum Islam di Indonesia Jakarta: Akademik Pressindo, 2015.

\footnotetext{
${ }^{30}$ Warkum sumitro, Legislasi Hukum Islam Transformatif, (Malang: Setara press, 2015), 23.

${ }^{31}$ H. Satria Effendi, dkk, Ushul Figh, (Surabaya : Prenada Media, Cet. Ke 7, 2017), 172173
} 
al-Qur'an dan Terjemahnya, Departemen Agama RI, 2000.

Effendi, H. Satria, dkk, Ushul Fiqh, Surabaya : Prenada Media, Cet. Ke 7, 2017.

Juknis pandaftaran dan pencatatan nikah Kantor Urusan Agama Kecamatan Jombang kabupaten Jombang.

Jumantoro, Totok, Kamus Usul Fiqh Jakarta: Sinar Grafika, 2005.

Keputusan Menteri Agama RI No. 477 Tahun 2004 tentang "Pencatatan

Nikah" Diterbitkan Seksi Urusan Agama Islam Kantor

Departemen Agama Kota Surabaya Tahun 2005.

Media Online Kabar Jombang tentang pencatatan dan pelaksanaan nikah di musim pandemic covid 19 Jombang.

Mustari, Mohamad dan Taufiq Rahman, Pengantar Metode Penelitian Yogyakarta: LaksBang Pressindo, 2012.

Papan Grafik kependudukan Kantor Urusan Agama kecamatan Jombang Kabupaten Jombang

Pedoman Pembantu Pegawai Pencatat Nikah, Proyek Peningkatan Tenaga Keagamaan Direktorat Jenderal Bimbingan Masyarakat Islam dan Penyelenggaraan Haji Departemen Agama Republik Indonesia, Jakarta : 2004.

Peta batas lokasi Kantor Urusan Agama kecamatan Jombang Kabupaten Jombang

Peta batas wilayah antar kecamatan Kantor Urusan Agama kecamatan Jombang Kabupaten Jombang

Prodjohamidjojo, MR. Martiman,, Hukum Perkawinan di Indonesia, Pasal 1 Undang-undang Nomor 1 Tahun 1974 tentang Perkawinan Indonesia Jakarta: Legal Center Publishing, 2007.

Siyoto, Sandu dan M. Ali Sodik, Dasar Metodologi Penelitan Yogyakarta: Literasi Media Publishing, Juni 2015.

Sumber : JHU CSSE COVID-19 Jombang.

Sumitro, Warkum, Legislasi Hukum Islam Transformatif, Malang: Setara press, 2015.

Wawancara dengan kepala KUA Kecamatan Jombang, H. Hasanuddin, S.Ag, M.Pd.I.

Wawancara dengan kepala Seksi Bimbingan Masyarakat Islam Kantor Kementerian Agama Kabupaten Jombang, H. Ilham Rohim, S.Ag, M.HI.

Wawancara dengan Penghulu JFU (Jabatan Fungsional Umum) KUA Kecamatan Jombang, Bapak Aan Sujatmiko, S.Ag, al-Hafidz.

Yanggo, H. Chuzaiman T. \& H A Hafiz Arshary A. Z, Problematika Hukum Islam Kontemporer. Jakarta: PT. Pustaka Firdaus, 2009.

Yusuf, A. Muri, Metode Penelitian Kuantitatif, Kualitatif \& Penelitian Gabungan, Jakarta: Kencana, 2014.

40 Abd. Basit Misbachul Fitri - Pelaksanaan KMA RI No. 298 